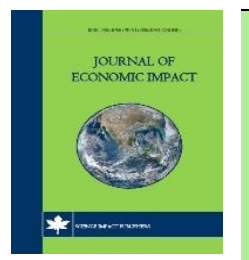

Available Online

Journal of Economic Impact

ISSN: 2664-9764 (Online), 2664-9756 (Print)

http://www.scienceimpactpub.com/jei

\title{
DETERMINANTS OF UNEMPLOYMENT IN SELECTED DEVELOPING COUNTRIES: A PANEL
} DATA ANALYSIS

\section{Ayesha Siddiqa}

School Education Department, Government of Punjab, Pakistan

\section{ARTICLE INFO}

\section{Article history}

Received: March 04, 2021

Revised: March 23, 2021

Accepted: March 24, 2021

\section{Keywords}

Unemployment

Panel data analysis

Developing countries

ADF

GMM

\section{ABSTRACT}

This research gives a new glimpse on determinants of unemployment in developing countries. Unemployment is not only a burning issue in developing countries but also in developed countries, but in this study, the case is related to developing countries. For this purpose data of ten selected developing countries has been taken for the period of 2000 to 2019 from the World Bank. Stationarity has been checked through the Augmented Dickey-Fuller (ADF) test and the result showed that all variables were stationary at 1st difference except the variable of inflation. The Generalized Method of Moments (GMM) model has been applied and results show that all variables are statistically significant. GDP, inflation, remittances, exchange rate, and expenditure on education has a negative impact on unemployment while population and external debt has a positive impact on unemployment. Policy recommendations are that if developing economies want to reduce unemployment they have to control population, remove deficit in the balance of payment, control the inflation rate, raise their GDP, earn the exchange rate due to increase in exports, and gain the foreign remittance and have to allocate the more budget on expenditure on education. In light of these recommendations, all economies can achieve economic efficiency and economic development.

*Email: siddiqagori@gmail.com

https://doi.org/10.52223/jei3012103

(C) The Author(s) 2021.

This is an open access article under the CC BY license (http://creativecommons.org/licenses/by/4.0/).

\section{INTRODUCTION}

The term unemployment refers to as, "no opportunity to do something for earning". When people are willing for a job and also able for this and seeking a job in order to meet their daily needs and other expenses of their lives but they have no any source of earning it is called unemployment. Unemployment in a country indicates low economic growth and low economic performance, unemployment also indicates that resources are not being fully utilized and the economy is working below the full capacity. According to the report of the bureau of labor statistics, unemployed workers and their families lose wages and inversely a nation also loses their participation in the economy to produce goods and services. In this way, unemployment also affects those who are also employed. Unemployment is not only the problem of developing countries but also the problem of developed countries, but it has severe effects on developing countries. The negative effects of unemployment in developing countries cause social isolation like psychological problems, loss of identity and self-esteem, increased stress from family, and social pressure. So it seems that developing countries must concentrate on the unemployment issue and create job opportunities for their citizen in such a way that the economy can grow and citizens can also take benefit from these opportunities.

Maqbool et al. (2013) said in their research that every government must use all factors of production in order to create employment opportunities for the unemployed workers. They also said that population expansion is a distressing issue in developing countries which creates many socio-economic problems in the developing economies. Increasing Population not only increases unemployment but also stockpiles unemployment. They 
said that due to no-job opportunities in home countries, the citizens have to migrate to other countries for getting a job. It is very high-risk for the future of a nation if others nations start to attract its brain-drain. The continuous brain-drain situation starts to deteriorate the economic growth of the countries. Persistent unemployment not only affects the dignity of a nation but also raises many cruel problems in home countries. Long-term unemployment creates too much immoral crime in countries like frustration, homelessness, poverty, family tension, loss of confidence, social isolation, self-esteem, and financial hardships. All these crimes not only spoils the economic growth of a country but also affect the economic development.

A person who has no job and other means to earn money cannot fulfill the needs of his or her family. So, an unemployed worker's family cannot take the advantages of the quality of education, medical facilities even they cannot create the assets which can create income for them. These conditions coerce indebtedness. Then, as a result of indebtedness, an unemployed person embellishes poverty for his family. This shows the positive relationship between unemployment and poverty. The major economic annoyance is poverty in developing countries. The biggest challenge of the $21^{\text {st }}$ century is to slash poverty (Alpizr and Ferraro, 2020). According to worldwide, about 700 million population or $10 \%$ of the total world population are just striving for basic necessities like food, shelter, pure drinking water, health, and education. They are also cladding to the utmost poverty. Approximately, the number of jobless people is 188 million globally. Globally, every night 821 million people go to bed with an empty stomach. These horrible situations gather international organizations and worldwide researchers to explore the main factors, determinants, and causes to root out this economic and social evil called poverty.

If the developing nations want to eliminate poverty, they should create employment opportunities. When people start to earn then they create income for themselves and for their families, which improves their living standard. Unemployment leads to low economic growth or low economic growth leads to unemployment. These two terms are interrelated to each other. Due to unemployment, the natural and human resources will be not utilized, when these resources will be idle the economy cannot grow. So if the economies of the developing nation want to grow and take participation in world trade and want to promote their living standard then these economies should create job opportunities in their nations.

Arslan and Zaman (2014) conducted research about unemployment determinants for Pakistan's economy for the period 1999-2010. They used FDI, GDP, Inflation, and population as independent variables and used Ordinary Least Square (OLS) for determining the results. They found in their study FDI, GDP, and inflation hurt unemployment while the population has a positive impact on unemployment. Their study also confirmed the trade-off between the variables of inflation and the rate of unemployment. Michael et al. (2016) investigated the interrelation between unemployment and economic growth for the period 1980-2013 in Nigeria. They used the co-integration test, VECM technique, and Granger causality test in their analysis. They take RGDP, UNR, and PEC (private consumption expenditure) as regressors. ADF test was applied to check stationarity and found that all variables stationary at a level except unemployment rate (UNR). UNR became stationary at first difference. The long-run relationship was found among the variables through the co-integration test. VCEM test showed unemployment had negative and significant relation with RGDP and unidirectional relationship found between UNR and RGDP through Granger causality test. The findings of the study revealed that the government should create opportunities for employment for unemployed workers and increasing the population.

Eita and Ashipala (2010) studied the causes of unemployment for the period 1971-2007 in Namibia. The unemployment model is estimated through the EngleGranger two-step test. The study revealed that there is a negative relationship between unemployment and inflation in Namibia and Phillips Curve held for Namibia. The study revealed that if investment increased then unemployment could be reduced and unemployment could also be reduced if aggregate demand increased. The wages concept is also used in the model. Cheema and Atta (2014) investigated unemployment determinants with the help of the ARDL test by taking the time series data from 1973-2010. The findings revealed that unemployment has a positive and significant relationship with the output gap, productivity, and economic uncertainty and negative relation with gross fixed investment and openness of trade. The study also revealed that the government should adopt the policies to reduce the restriction on trade and the government should also encourage private investment. Aqil et al. (2014) investigated the factors that influence employment levels in Pakistan. GDP growth rate, inflation, FDI, and population were taken as explanatory variables. The correlation and multiple regression revealed that GDP and inflation have no significant relation with unemployment, but FDI and population have a significant and negative relationship with unemployment.

Maqbool et al. (2013) investigated the impact of different factors on the unemployment rate in Pakistan 
by using time series data for 1976 to 2012. They used population, foreign direct investment, gross domestic product, and inflation as independent variables. ARDL test was applied to test the determinants of UN. Empirical results revealed that these explanatory variables have a significant relationship with unemployment in Pakistan in the short run as well as the long run. The CUSUM and CUSUMQ showed that the model was structurally stable within $5 \%$ of the critical bound. They also found that the Phillip curve also exists in Pakistan. Oniore et al. (2015) investigated the determinants of unemployment in Nigeria by taking the time series data. The results indicated that GDP, inflation, degree of openness, and private domestic investment have significant relation with unemployment in the short run, particularly for the period under consideration. The Johansen co-integration test showed the long-run relationship among the variables and negative signs. The ECM showed the high speed of adjustment from short-run to long-run equilibrium. The study also revealed that government should encourage private investment at all levels and also reduced the restrictions on trade and support the openness of trade.

Trimurti and Komalasari (2014) investigated unemployment, minimum wage, inflation, and economic growth by taking data from seven provinces of Indonesia for the period of 2004 to 2012. The finding of this research revealed that the economic growth and unemployment variables have insignificant effects on unemployment. The finding of the study showed that inflation and unemployment have a significant and positive impact on unemployment while the variables of the minimum wage have an insignificant impact on the variable of unemployment. Riaz and Zafar (2018) studied the factors which determined the unemployment in Pakistan. The data was taken from 1999-2015 and found the empirical relationship with GDP, pop, T\&V education, and degree colleges and universities enrollment. ARDL test is used. Long-run results revealed that there is a negative relationship between GDP and unemployment. The population has a positive and significant relation with unemployment while $\mathrm{T} \& \mathrm{~V}$ education has positive and insignificant relation with unemployment. The short-run ECM-1 showed a negative and significant relation with unemployment. The CUSUM and CUSUMQ showed that the model was structurally stable within critical bound at a 5\% level of significance. Alrabba (2017) investigated the determinants of the unemployment rate in Jordan during the period (1992-2015). To check the stationarity ADF test was applied, and found the variables were stationary at different levels. Granger causality, impulsive response function, and variance decomposition were applied by applying the VAR model. The findings of the study showed that private investment negatively affects the unemployment rate in Jordan, which explained overall $2.64 \%$ imbalances in the unemployment rate in the $2^{\text {nd }}$ period and $(1.58 \%)$ in the $4^{\text {th }}$ period. This weightage also declined up to a level at which the explanatory power of private investment for the forecast error in the unemployment rate can reach $1.34 \%$ in the $9^{\text {th }}$ period.

Meo et al. (2020) gave a fresh idea about the non-linear relationship between unemployment, governance, and poverty in Pakistan. The data were taken from 19842016 by applying the non-linear ARDL co-integration test. They found that poverty responded asymmetrically due to positive or negative disturbances in UN and governance. Their study gave the idea that the nonlinear behavior of poverty must be considered while making policies by policymakers for better policy-making. Kamran et al. (2014) investigated the unemployment determinants for the period 1981-2010 in Pakistan with the help of a regression model, descriptive stats, and graphs. They took population, interest rate, FDI, GDP, and literacy rate as explanatory variables. The state of democracy also took into consideration. They found positive relation of pop with $U N$ and a negative relationship with literacy and FDI. They also described the rural and urban employment differences. They also used dummy variables for political regimes. Imtiaz et al. (2020) investigated empirically the determinants that effecting youth unemployment in Pakistan. They took the political instability, lack of investment, the backwardness of the agriculture sector, and overpopulation as explanatory variables. They found the young people, age (15-24), mostly affected by the existing recession. They also discussed the desire for better employment circumstances, policy evaluation, and assessment of the reasons to assist in providing more advanced jobs for youth. The findings revealed that the explanatory variables had a significant effect on youth unemployment. Mahmood et al. (2014) examined the relationship between unemployment and different factors. First of all, normality, independence, homoscedasticity, and auto-correlation were found. The model was selected by applying stepwise regression by using the data from 1990-2010. According to the estimated results labor force had a positive effect on unemployment while inflation had a negative impact on unemployment.

\section{METHODOLOGY}

A panel data from 2000 to 2019 has been used for finding the determinants of unemployment in selected 10 developing countries. Secondary data has been taken 
from the World Bank for these countries i.e. Pakistan, Iran, Malaysia, Oman, Nepal, Russia, Philippines, Turkey, Uganda, and Brazil. The equation of the model is given below as:

$\mathrm{UN}_{\mathrm{it}}=\beta_{0}+\beta_{1} \mathrm{GDP}_{\mathrm{it}}+\beta_{2} \operatorname{Inf}_{\mathrm{it}}+\beta_{3}$ Pop $_{\mathrm{it}}+\beta_{4} \mathrm{Rem}_{\mathrm{it}}+$

$\beta_{5}$ Exdebt $_{i t}+\beta_{6}$ Exrate $_{i t}+\beta_{7}$ Expedu $_{\text {it }}+\mu$
Unemployment is the dependent variable and independent variables are gross domestic product, inflation remittances, population, external debt, exchange rate, expenditure on education as shown in Table 1. It is derived from the labor force minus employed work. If normally defined as when a person wants to work but has no job.

Table 1. Variables of the study.

\begin{tabular}{llc}
\hline Short-form & Expanded form & Unit of measurement \\
\hline UN & Unemployment & $\%$ \\
GDP & Gross Domestic Product & US\$ \\
INF & Inflation & CPI \\
Rem & Remittances & Received US\$ \\
Pop & Population & Total \\
Exdebt & External debt & GNI US\$ \\
Exrate & Exchange rate & US\$ of GDP \\
Expedu & Expenditure on education & \% \\
\hline
\end{tabular}

The gross domestic product is negatively related to unemployment. GDP is the market value of all services and goods produced in an economy. An increase in GDP creates employment opportunities and reduces unemployment. Inflation could also have a significant relationship with unemployment. There is a trade-off between inflation and unemployment, this trade-off indicates the Philip curve. Remittances could negatively affect unemployment. It is money that is sent home by migrants competes with international aid as one of the largest financial inflows to developing countries. The population is taken as total and has a positive relation to unemployment. Population expansion is followed by an increase in the labor force of the community which leads a substantial chunk of the population to unemployment. The increasing population has severe implications on poverty also.

External debt could have a positive relation to unemployment. It is a total debt which the residents of a country owe to foreign creditors. The exchange rate could have a negative relation to unemployment. It is the price of one currency in terms of another currency. Expenditure on education could negatively affect unemployment. When the education standard is raised it creates job opportunities for skilled educators and it becomes the source of earning for them.

\section{RESULTS AND DISCUSSION}

Table 2 is about the descriptive statistics of the variables before analysis. Descriptive statistics present the raw data in meaningful form, which allows simpler interpretation of the data, interpretation of raw data is very difficult and time-wasting, so to avoid this dilemma we use descriptive statistics. In Table 2 there are eight variables and each variable has 200 observations. The mean, medium. Maximum, minimum values, standard deviation, kurtosis, etc. are given. So from descriptive stats, one can predict his analysis.

Table 2. Descriptive statistic of variables used in this study.

\begin{tabular}{lcccccc}
\hline Variables & Mean & Median & Max & Min & S.D & Obs \\
\hline UN & 18.1959 & 15.6045 & 61.628 & 0.628 & 13.10572 & 200 \\
GDP & $1.59 \mathrm{E}+11$ & $8.87 \mathrm{E}+10$ & $6.55 \mathrm{E}+11$ & $5.49 \mathrm{E}+09$ & $1.89 \mathrm{E}+11$ & 200 \\
INF & 20.63802 & 16.43439 & 73.91537 & 0.183333 & 16.93454 & 200 \\
POP & 74461881 & 63955411 & $1.75 \mathrm{E}+08$ & 2267973 & 57562555 & 200 \\
REM & $1.57 \mathrm{E}+09$ & $5.18 \mathrm{E}+08$ & $6.92 \mathrm{E}+09$ & 39000000 & $2.19 \mathrm{E}+09$ & 200 \\
EXDEBT & $1.56 \mathrm{E}+11$ & $8.89 \mathrm{E}+10$ & $6.37 \mathrm{E}+11$ & $5.51 \mathrm{E}+09$ & $1.83 \mathrm{E}+11$ & 200 \\
EXPEDU & 11.91828 & 11.59382 & 23.03064 & 1.83782 & 5.945186 & 200 \\
EXRATE & 370.8034 & 45.66071 & 1783.856 & 0.3845 & 674.3426 & 200 \\
\hline
\end{tabular}


Table 3. Correlation of the variables.

\begin{tabular}{lcccccccc}
\hline variable & UN & GDP & INF & POP & REM & EXDEBT & EXRATE & EXPEDU \\
\hline UN & 1 & 0.107 & 0.295 & 0.075 & -0.128 & 0.110 & 0.562 & 0.492 \\
GDP & 0.107 & 1 & 0.308 & 0.733 & 0.129 & 0.999 & -0.278 & 0.098 \\
INF & 0.295 & 0.308 & 1 & 0.149 & 0.371 & 0.313 & -0.066 & 0.400 \\
POP & 0.075 & 0.733 & 0.149 & 1 & 0.136 & 0.735 & -0.242 & 0.103 \\
REM & -0.128 & 0.129 & 0.371 & 0.136 & 1 & 0.146 & -0.267 & 0.089 \\
EXDEBT & 0.110 & 0.999 & 0.313 & 0.735 & 0.146 & 1 & -0.277 & 0.102 \\
EXRATE & 0.562 & -0.278 & -0.066 & -0.242 & -0.267 & -0.277 & 1 & 0.081 \\
EXPEDU & 0.492 & 0.098 & 0.400 & 0.103 & 0.089 & 0.102 & 0.0814 & 1 \\
\hline
\end{tabular}

Correlation is a statistical analysis that is used to check the intensity of the relationship between two quantitative variables. The results given in Table 3 shows how much one variable changes with the change in other variables. It also provides the linear relationship between two variables. The correlation value ranges between -1 and +1 from the above matrix can be seen where unemployment shows positive relation to GDP, inflation, population, external debt, exchange rate, and expenditure on education and negative relation to remittances.

Table 4. Unit root test.

\begin{tabular}{|c|c|c|c|c|}
\hline \multirow{2}{*}{ Variables } & \multicolumn{2}{|c|}{ Level 1(0) } & \multicolumn{2}{|c|}{ 1st difference } \\
\hline & t value & Probability value & t value & Probability value \\
\hline$\overline{\mathrm{UN}}$ & -3.273006 & 0.0175 & -14.31437 & 0.0000 \\
\hline GDP & -1.318996 & 0.6207 & -14.03693 & 0.0000 \\
\hline Inflation & -2.986624 & 0.0379 & - & - \\
\hline Pop & -1.810828 & 0.3745 & -14.00141 & 0.0000 \\
\hline Rem & -1.883588 & 0.3396 & -14.00008 & 0.0000 \\
\hline Exrate & -2.532870 & 0.1092 & -14.00033 & 0.0000 \\
\hline Exdebt & -1.315458 & 0.6224 & -14.03710 & 0.0000 \\
\hline Expedu & -4.765864 & 0.0001 & -14.71542 & 0.0000 \\
\hline
\end{tabular}

To run the regression for analysis, the first stationarity of all variables has been checked that whether they are stationary at level or 1 st difference. For this purpose unit root test is applied as shown in Table 4 to check whether a time series or panel variables are non-stationary and possess a unit root. The null hypothesis is generally defined as the presence of a unit root and the alternative is either stationarity, trend stationary, or explosive root depending on the test. In this study to check the stationarity of variables ADF test has been applied. And results show that all variables including the dependent variable are stationary at 1 st difference except inflation. Inflation is stationary at level.

Table 5. Lags selection.

\begin{tabular}{lcccccc}
\hline Lag & LogL & LR & FPE & AIC & SC & HQ \\
\hline 0 & -21607.31 & NA & $8.51 \mathrm{E}+85$ & 220.5644 & 220.6982 & 220.6186 \\
1 & -19517.91 & $3986.926^{*}$ & $9.01 \mathrm{e}+76^{*}$ & $199.8970^{*}$ & $201.1012^{*}$ & $200.3845^{*}$ \\
2 & -19501.56 & 29.86228 & $1.47 \mathrm{E}+77$ & 200.3833 & 202.6579 & 201.3041 \\
3 & -19498.47 & 5.39053 & $2.76 \mathrm{E}+77$ & 201.0048 & 204.3498 & 202.359 \\
4 & -19495.34 & 5.210834 & $5.21 \mathrm{E}+77$ & 201.6259 & 206.0413 & 203.4135 \\
\hline
\end{tabular}


The purpose of choosing the optimal lag length is to reduce residual correlation. For this, the optimal lag length is chosen by AIC which shows that the optimal length for this panel analysis is 1 as shown in Table 5 . Unemployment is a burning issue especially nowadays in COVID-19 situation. It's not a problem of only one economy but also the problem of the whole world whether it is a developed or developing nation. It brings negative effects upon the unemployed as they are jobless and suffering worse circumstances to find a new job and those who are employed feel less secure to keep their jobs in the future. This study about unemployment in which 10 developing countries have been selected to investigate the determinants of unemployment. In this study, the determinants of unemployment are gross domestic product, inflation, population, remittances, external debt, exchange rate, and expenditure on education. Ten selected countries are Pakistan, Malaysia, Iran, Oman, Nepal, Russia, Philippines, Turkey, Uganda, and Brazil. The data has been taken for the period 2000 to 2019 from the World Bank. Analysis has been done with the Eviews-10. First, stationary has been checked through the ADF test and find that all variables are stationary at $1^{\text {st }}$ difference except inflation. Correlation has been checked and the Generalized Method of Moment (GMM) has been applied.

Table 6. Results of the selected variables.

\begin{tabular}{lcccc}
\hline Variables & Coefficient & S. Error & T. statics & Prob. \\
\hline UN(-1) & 1.027467 & 0.004487 & 228.9663 & 0.0000 \\
GDP(-1) & $-1.60 \mathrm{E}-09$ & $2.74 \mathrm{E}-10$ & -5.818188 & 0.0000 \\
INFLATION & -0.010227 & 0.003831 & -2.669833 & 0.0083 \\
POP(-1) & $4.20 \mathrm{E}-08$ & $1.62 \mathrm{E}-08$ & 2.590312 & 0.0104 \\
REM(-1) & $-4.65 \mathrm{E}-09$ & $5.81 \mathrm{E}-10$ & -8.004295 & 0.0000 \\
EXDEBT(-1) & $1.55 \mathrm{E}-09$ & $2.81 \mathrm{E}-10$ & 5.512221 & 0.0000 \\
EXRATE(-1) & -0.027767 & 0.001204 & -23.05944 & 0.0000 \\
EXPEDU(-1) & -1.428802 & 0.05488 & -26.03496 & 0.0000 \\
C & -0.514639 & 0.159904 & -3.218436 & 0.0015 \\
\hline R & 0.997018 & Mean dep. V & 18.28418 \\
Adj R & 0.996791 & S.D. dep. V & 13.07902 \\
S.E. of Reg. & 0.740902 & Sum squared resid & 101.0042 \\
D.W & 2.041802 & J-statistic & 7.352334 \\
Instrument rank & 16 & Prob(J-statistic) & & 0.006698 \\
\hline
\end{tabular}

Unemployment has negative relation with the gross domestic product, inflation, remittances, exchange rate, expenditure on education, and positive relation with population and external debt as shown in Table 6. All variables are statistically significant. R squared measures the goodness of fit, its value is 0.99 means that 0.99 variations in unemployment are explained by the under-study variables. If $\mathrm{R}^{2}>\mathrm{DW}$ statistics then the regression must be spurious but in this study, it can be seen that the case is opposite $\mathrm{R}^{2}<\mathrm{DW}$ so the regression is not spurious the model is too fit. The Gross Domestic Product (GDP) has a negative and significant impact on unemployment. The coefficient of GDP shows that there is a -1.60 unit decrease in unemployment due to a one-unit increase in GDP. Inflation also has a negative impact on unemployment. The inflation coefficient shows that there is a -0.01 unit decrease in unemployment if inflation increases by one unit.

Remittances have a negative impact on unemployment too. The unemployment decrease -4.65 unit if remittances increase by one unit.it has also a significant impact on unemployment. The population has a positive and significant impact on unemployment. The coefficient of pop shows that unemployment will rise by 4.20 units if pop rises by one unit. External debt has also positive and significant relation to unemployment. The coefficient shows that unemployment increases by 1.55 units if External debt increases by one unit. The exchange rate has a negative and significant impact on unemployment. The coefficient of the exchange rate shows that there is a -0.02 unit decrease in unemployment if the exchange rate increases by one unit. 
The expenditure on education has a negative and significant impact on unemployment. The coefficient value of education expenditure shows that there is a 1.42 unit decrease in unemployment due to a one-unit increase in education expenditure. The results revealed that gross domestic product, inflation, exchange rate, remittances, expenditure on education has a negative and significant relation to unemployment, and population and external debt has a positive relation to unemployment.

\section{CONCLUSIONS}

The underlying variables of the study show that unemployment is greatly affected by these variables and respond according to their relation. It is concluded from the results that to reduce unemployment in developing countries all developing economies should increase their GDP. Because an increase in GDP creates employment opportunities in the economy. An increase in inflation also reduces unemployment. Because high prices demand more money, and more money can only be generated by employment opportunities. Remittances also lead to a decrease in unemployment, which has also a significant and negative impact on unemployment. Population leads to an increase in unemployment. So the study suggests that if we want to reduce unemployment we have also to control the population expansion. External debt creates a deficit in the balance of payment, the burden of external debt leads to a decrease in employment. The economy starts to move towards the depression situation. So if developing countries want to grow they should decrease their imports and increase their exports. The exchange rate is a good step for improvement in economies. If the developing economies want to increase their exports they must depreciate their currency, it will lead to an increase in demand for their products in other countries so in this way they can earn foreign currency. The expenditure on education has a negative and significant impact on unemployment. To reduce the unemployment level there is a need to increase the expenditure on education.

\section{REFERENCES}

Alpízar, F., Ferraro, P.J., 2020. The environmental effects of poverty programs and the poverty effects of environmental programs: the missing RCTs. World Development, 127, 104783.

Alrabba, M.I.M., 2017. The determinants of unemployment rate in Jordan: a multivariate approach. International Journal of Economics and Finance, 9(11), 109-117.
Aqil, M., Qureshi, M.A., Ahmed, R.R., Qadeer, S., 2014. Determinants of unemployment in Pakistan. International Journal of Physical and Social Sciences, 4(4), 676.

Arslan, M., Zaman, R., 2014. Unemployment and its determinants: a study of Pakistan economy (19992010). Journal of Economics and Sustainable development, 5(13), 20

Cheema, A.R., Atta, A., 2014. Economic determinants of unemployment in Pakistan: co-integration analysis. International journal of business and social science, 5(3).

Eita, J.H., Ashipala, J.M., 2010. Determinants of unemployment in Namibia. International Journal of Business and Management, 5(10), 92.

Imtiaz, S., ArshadAli, Z.K., Ullah, M., Khan, M., Jacquemod, J., 2020. Determinants of youth unemployment in Pakistan. International Journal of Economics and Financial Issues, 10(5), 171-177.

Kamran, A., Shujaat, S., Syed, N.A., Ali, S.N., 2014. A study on determinants of unemployment in Pakistan. In Proceedings of the Seventh International Conference on Management Science and Engineering Management, 1337-1348. Springer, Berlin, Heidelberg.

Mahmood, T., Ali, A., Akhtar, N., Iqbal, M., Qamar, S., Nazir, H.Z., Abba, N., Sana, I., 2014. Determinants of unemployment in Pakistan: a statistical study. International Journal of Asian Social Science, 4(12), 1163-1175.

Maqbool, M.S., Mahmood, T., Sattar, A., Bhalli, M.N., 2013. Determinants of unemployment: empirical evidences from Pakistan. Pakistan Economic and Social Review, 51(2),191-208.

Meo, M.S., Kumar, B., Chughtai, S., Khan, V.J., Dost, M.K.B., Nisar, Q.A., 2020. Impact of unemployment and governance on poverty in Pakistan: a fresh insight from non-linear ARDL co-integration approach. Global Business Review, 1-18. doi:10.1177/0972150920920440

Michael, E.O., Emeka, A., Emmanuel, E.N., 2016. The relationship between unemployment and economic growth in Nigeria: Granger causality approach. Research Journal of Finance and Accounting, 7(24), 153-162.

Oniore, J.0., Bernard, A.O., Gyang, E.J., 2015. Macroeconomic determinants of unemployment in Nigeria. International Journal of Economics, Commerce and Management, 3(10), 215-230.

Riaz, A., Zafar, F., 2018. Determinants of unemployment in less developed countries. In SHS Web of Conferences (Vol. 48). EDP Sciences. 
Trimurti, C.P., Komalasari, Y., 2014. Determinants of province in Indonesia. Scientific Research Journal unemployment: empirical evidences from 7 (SCIRJ), 2(8), 5-9.

Publisher's note: Science Impact Publishers remain neutral with regard to jurisdictional claims in published maps and institutional affiliations.

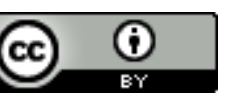

Open Access This article is licensed under a Creative Commons Attribution 4.0 International License, which permits use, sharing, adaptation, distribution and reproduction in any medium or format, as long as you give appropriate credit to the original author(s) and the source, provide a link to the Creative Commons license and indicate if changes were made. The images or other third-party material in this article are included in the article's Creative Commons license, unless indicated otherwise in a credit line to the material. If material is not included in the article's Creative Commons license and your intended use is not permitted by statutory regulation or exceeds the permitted use, you will need to obtain permission directly from the copyright holder. To view a copy of this license, visit https://creativecommons.org/licenses/by/4.0/. 